\title{
Designing a Virtual Laboratory Using Android-Based Virtual Reality (Case Study: Laboratory of Basic Measurement and Electrical Engineering Instrumentation)
}

\author{
Syahrir ${ }^{1, \mathrm{a}, *}$ \\ ${ }^{1}$ Electrical Engineering Department, Politeknik Negeri Ujung Pandang, Makassar, Indonesia \\ a,* syahrir@poliupg.ac.id (Corresponding Author)
}

\begin{abstract}
The existence of a laboratory in an engineering department is very important. The reality is that not all students can use existing laboratories in the engineering department due to limited laboratory space, tools and time constraints. There are various kinds of technological developments that have occurred to date. One of these very rapid developments has led to digital technology which is increasingly favored by the community such as VR ( Virtual Reality ) technology which is able to provide the worldvirtual. Therefore, VR technology is used to solve student's problems in accessing the laboratory. In this paper, we propose VR design for learning in the laboratory. The results of the questionnaire experiment show that respondents can use the application well at $\mathbf{7 8 . 4 \%}$ or very well, the application features run well at $79.6 \%$ or well, and the application can be used in the measurement laboratory at $80.4 \%$ or very well.
\end{abstract}

Keywords-Laboratory; Virtual Reality; Android; 3d

\section{Introduction}

The existence of technology, especially smartphones, which are now increasingly developing, must be addressed wisely. The phenomenon of the high number of smartphone users is certainly a challenge and opportunity in the world of education [1], [2]. The existence of smartphones also brings great opportunities to develop technology that is useful in the field of education. The benefits that can be taken from the existence of this technology are to use it as an effective, creative and educational media for learning. So that educational application media can continue to be developed, one of which is Virtual Reality (VR) technology [3], [4].

VR is a technology that allows users to interact with an environment that is simulated by a computer (computer - simulated - environment ), an actual environment that is imitated or really an environment that only exists in the imagination [5], [6].

Politeknik Negeri Ujung Pandang (PNUP) is one of the polytechnis that uses practical learning. Understanding the fundamental of principal measurement laboratory electronic devices and instrumentation is elementry competency that must be mastered by PNUP students majoring in Electrical Engineering, Multimedia and Network Engineering study programs, and Telecommunication Engineering. In this course, students are expected to be familiar with electronic components and be able to make simple electronic circuits [7], [8]. However, because practicum activities are still monotonous and the availability of practical tools is limited, it makes students have difficulty understanding and recognizing electronic components. In addition, the existence of learning media seems less attractive and has not been used optimally [9], [10]. Therefore, many students are bored, feel bored and less interested, which will reduce students' understanding of the material presented by the lecturer [11], [12].

Based on these problems, the learning media that can be developed is the Virtual Laboratory of Basic Measurement and Instrumentation for Electrical Engineering learning media using VR technology on the Android platform [13], [14]. 


\section{Research Methodology}

\section{A. Design Procedure}

The design method is needed so that the research can be structured so that the results obtained are in accordance with the research objectives. The system to be built is a system based on learning applications in the introduction of a series of electronic components that are connected using virtual reality technology. The design method used is the waterfall method. The waterfall method is often called the classic life cycle, the name of this model is actually the "Linear Sequential Model", which describes a systematic and sequential approach to software development, starting with the specification of user needs and then continuing through the stages. planning, modeling, construction, as well as the delivery system to the users (deployment), which ended with a complete software support generated.

In general, this design model is systematic from one stage to the next stage. The research flow can be seen in figure 1 .

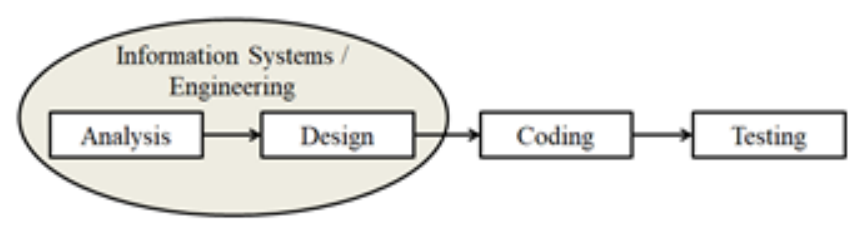

Figure 1. Stages of Research with the Waterfall

1. Analysis Phase

At the analysis stage, the system developer requires communication which aims to understand the software expected by the user and the software's limitations. This information can usually be obtained through interviews, discussions or in-person surveys. Information is analyzed to obtain data needed by users. In this study, information was obtained through direct surveys to the laboratory for basic measurement and instrumentation.

\section{Design Stage}

The design stage is the stage where the existing needs in the previous stage are made into a system design. So that you can see a picture of the form of the system to be made. Designs can be design user interface, database design, business processes and others. In this study, the design uses a 3D blender application to create the required environment for virtual laboratory applications.

3. The coding stage

The coding stage is the implementation of the design stage. The system description in the previous stage is implemented in the form of coding to produce the final system or the finished system. In this study, the coding was implemented using the unity $3 \mathrm{~d}$ application.

\section{Testing Phase}

The testing stage is the stage where the system or application that has been made is tested. Whether the system is feasible or still needs improvement. Testing is usually done to see if the system is still in error or not even running. If the system is deemed good, the system can be applied. In this study, testing was carried out using 2 methods, namely the black box method and the user acceptance testing method .

\section{B. Application Design}

In implementing this activity, the implementation of this village stage can be seen in the image below.

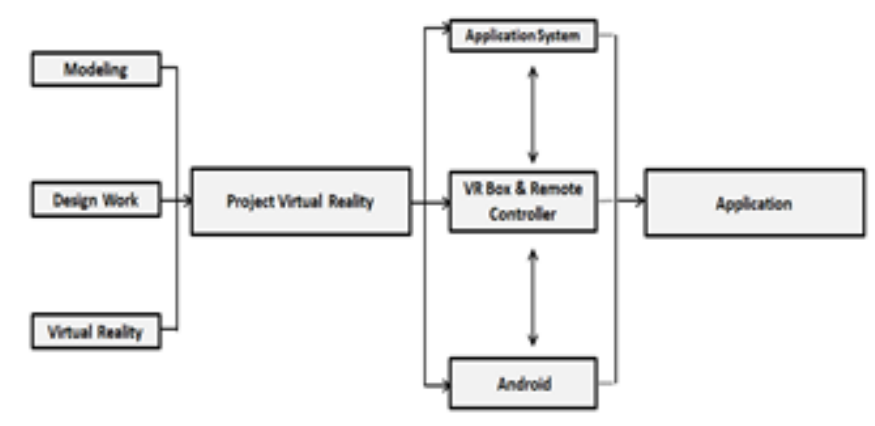

Figure 2 . Explanation of Flow and Application Development

Figure 2 describes the flow of making the application to be made. The first step is to make $3 \mathrm{D}$ object modeling using a 3D blender application, the objects created include an environment with a background in the Laboratory of Basic Measurement and Instrumentation for Electrical Engineering and laboratory tools for basic 
measurement and instrumentation to be used. Designing a system work design using a unity application. System that is run using a computer program language. As well as a virtual reality feature that can change the user's place as if leaving the real world and enter the virtual laboratory for basic measurement and instrumentation. All these things are then combined into a virtual reality project which will produce an application that can be run on the Android platform with the help of a virtual reality box and a bluetooth joystick controller .

\section{Results and Discussion}

The results of this study are in the form of learning media applications to determine the steps that must be taken to make a series so as to produce a series form like the one in . This application has been designed based on android and objects designed in 3D are almost similar to the original form and is equipped with voice description facilities that are activated automatically so that students can easily use this application.

\section{A. Results}

The results of the interface in the application can be seen in the image below:

\section{Application Main Menu Interface}

The main view of this application is a display applications that are ready to use.

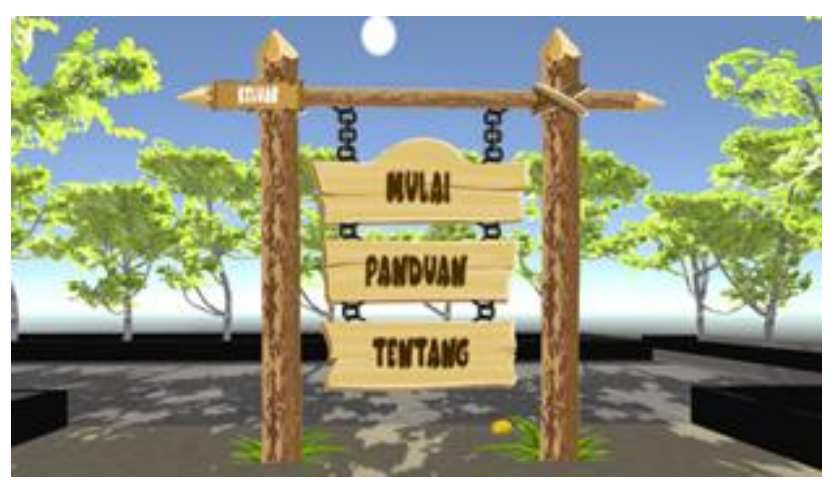

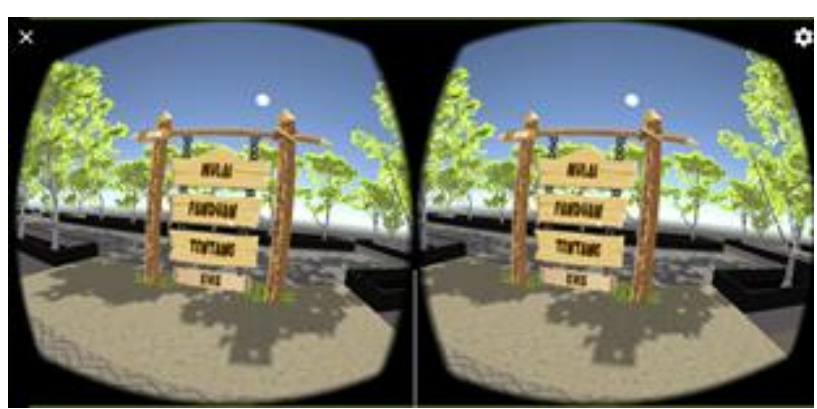

Figure 3 . Application Main Menu Interface

On the main menu there are five buttons, namely the exit button to exit the application, the button starts directing the user to the main laboratory scene, the button about directing the user to find out information about the laboratory and the developer, the guide button directs the user to learn how to use the application and the guide for joobsheets, especially chapters 8 and 9 , and the quiz button directs the user to the quiz scene .

\section{Start Menu Interface}

Features on the menu start introducing practical tools such as $3 \mathrm{D}$ objects, sound and text.

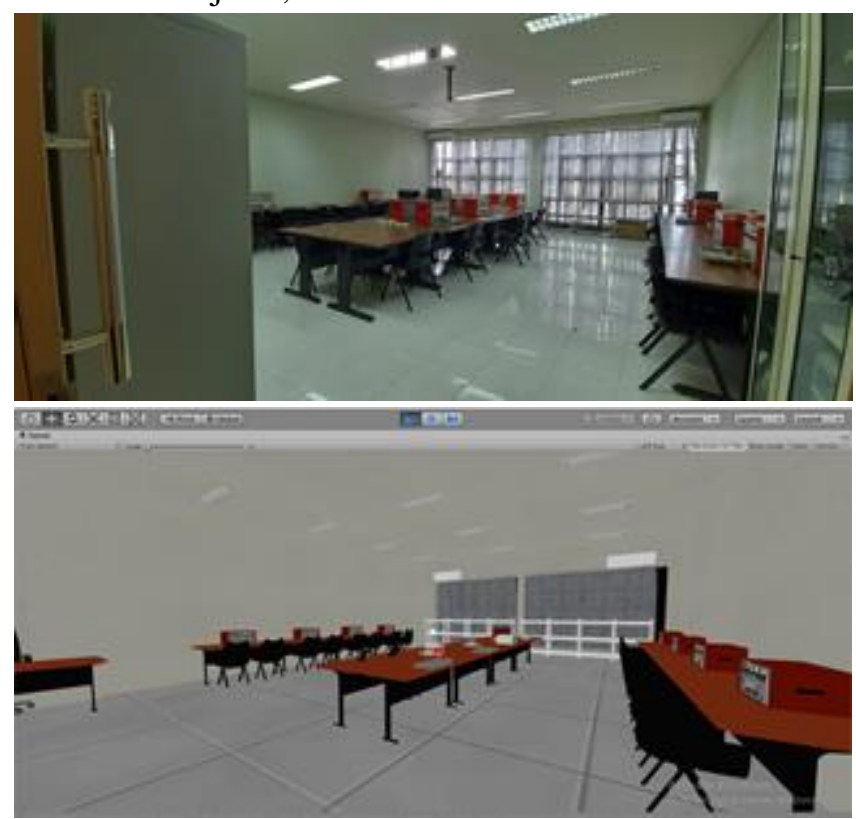




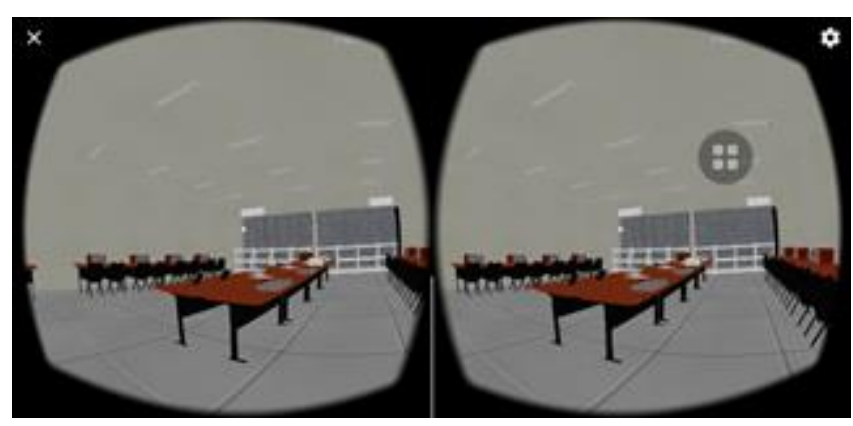

Figure 4 . Start Menu Interface

On the start menu display displays the $3 \mathrm{~d}$ object environment with a laboratory background of basic measurements and instrumentation and displays 3D objects for practicum tools that will be used in joobsheet chapter 8 and chapter 9 . On the start menu there is also a menu for selecting joobsheet chapter 8 and chapter 9 .

\section{Interface Select Joobsheet}

At the scene's heart is a menu to choose joobsheet which consists of three buttons, namely buttons chapters 8 and button Chapter 9 which will lead to a scene Chapter 8 and Chapter 9 contains a series of animated $3 \mathrm{D}$ objects and referrals to complete the circuit in the form of text and sound.

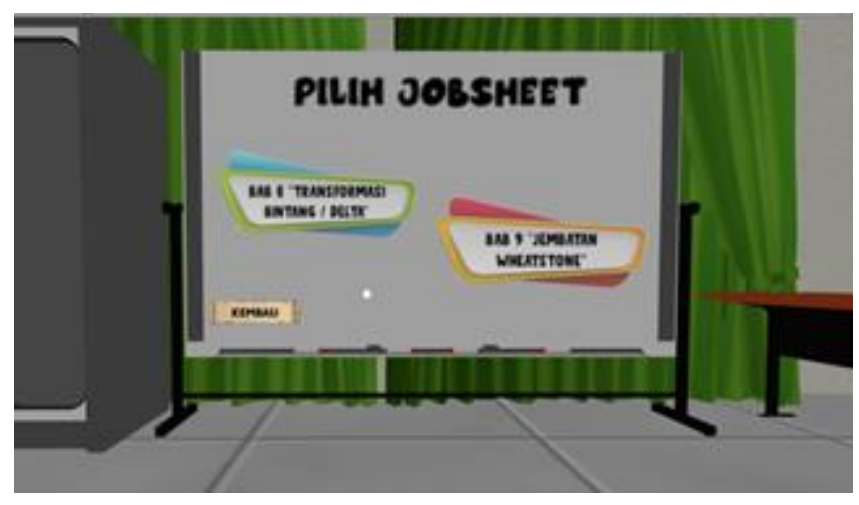

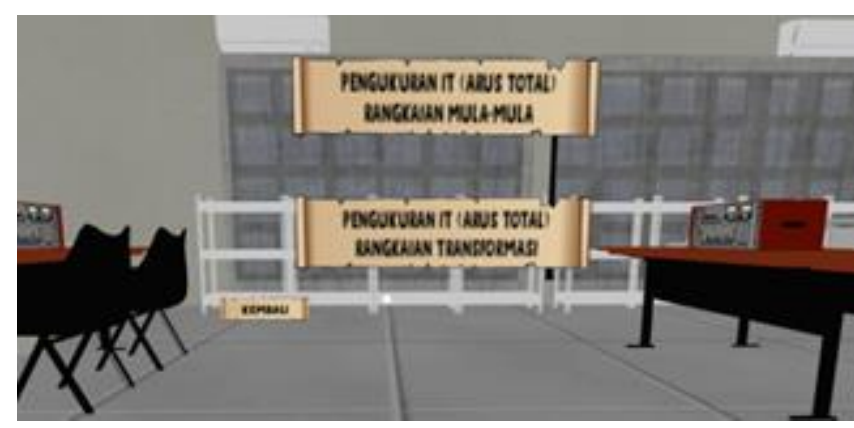

Figure 5 . Interface Select Joobsheet

\section{Interface Select Joobsheet Quiz}

In the quiz scene, there is text to display quiz questions, four buttons for choices, namely button $\mathrm{A}$, button $\mathrm{B}$, button $\mathrm{C}$, and button $\mathrm{D}$, and there is a label to display the score in text.
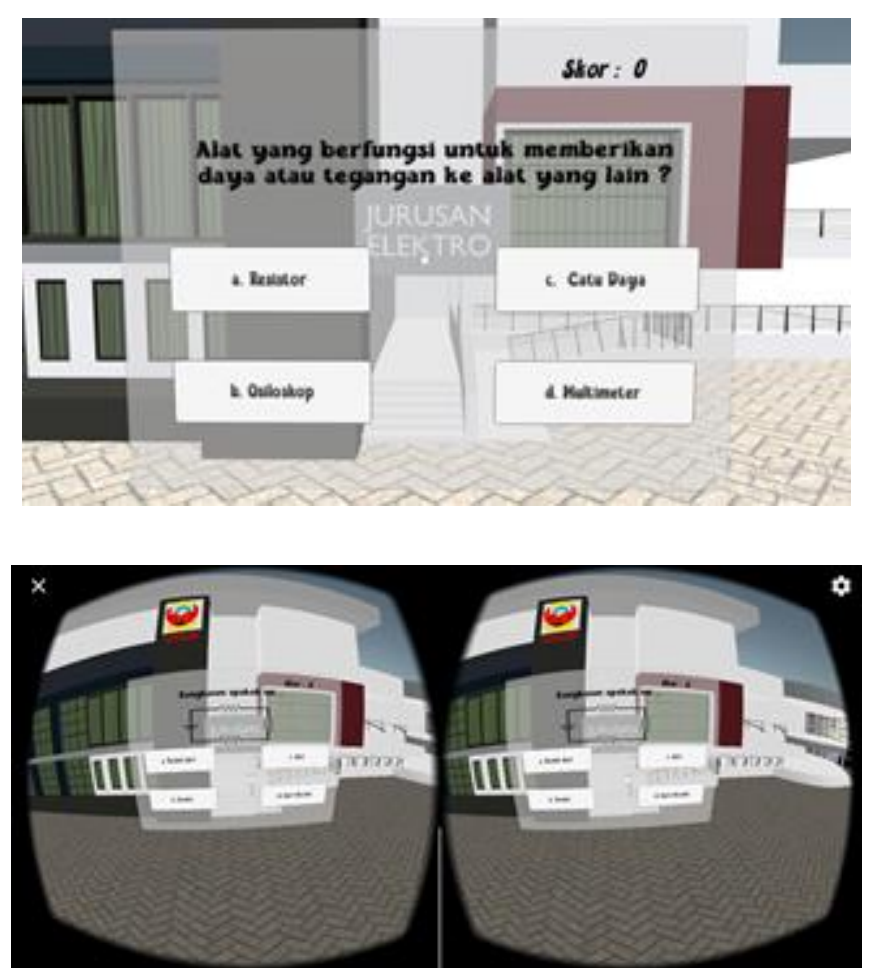

Figure 6. Interface Quiz

\section{B. Discussion}

\section{Black-Box Testing}

Testing of this application is carried out by the black box or black box testing method, where the black box software testing method aims to ensure that the functions 
of the applications that have been built can run properly and to find out whether there are still program errors or not

Table 1. Black Box Testing Table

\begin{tabular}{|c|c|c|c|c|}
\hline No & $\begin{array}{c}\text { Testing } \\
\text { Scenarios }\end{array}$ & Running script & $\begin{array}{l}\text { Expected } \\
\text { results }\end{array}$ & Result \\
\hline 1 & $\begin{array}{l}\text { The user is } \\
\text { directed } \\
\text { to the main } \\
\text { menu scene }\end{array}$ & $\begin{array}{l}\text { GvrEditorEmulato } \\
\text { r.cs } \\
\text { GvrPointerInputM } \\
\text { odule.cs } \\
\text { GvrControllerInpu } \\
\text { t.cs } \\
\text { GvrPointerPhysics } \\
\text { Raycaster.cs } \\
\text { GvrReticlePointer } \\
\text {.cs } \\
\text { Main Menu2.cs } \\
\text { menuload.cs } \\
\text { menu.cs } \\
\text { PlayerWalk.cs }\end{array}$ & $\begin{array}{l}\text { Displays menu } \\
\text { options }\end{array}$ & It works \\
\hline 2 & $\begin{array}{l}\text { The user } \\
\text { selects the } \\
\text { start menu }\end{array}$ & $\begin{array}{l}\text { GvrEditorEmulato } \\
\text { r.cs } \\
\text { GvrPointerInputM } \\
\text { odule.cs } \\
\text { GvrControllerInpu } \\
\text { t.cs } \\
\text { GvrPointerPhysics } \\
\text { Raycaster.cs } \\
\text { GvrReticlePointer } \\
\text {.cs } \\
\text { Main Menu.cs } \\
\text { menuload.cs } \\
\text { menu.cs } \\
\text { PlayerWalk.cs }\end{array}$ & $\begin{array}{l}\text { Shows the main } \\
\text { laboratory scene }\end{array}$ & It works \\
\hline 3 & $\begin{array}{l}\text { The user } \\
\text { selects the } \\
\text { guide menu }\end{array}$ & $\begin{array}{l}\text { GvrEditorEmulato } \\
\text { r.cs } \\
\text { GvrPointerInputM } \\
\text { odule.cs } \\
\text { GvrControllerInpu } \\
\text { t.cs } \\
\text { GvrPointerPhysics } \\
\text { Raycaster.cs } \\
\text { GvrReticlePointer } \\
\text {.cs } \\
\text { Main Menu2.cs } \\
\text { menuload.cs } \\
\text { menu.cs } \\
\text { PlayerWalk.cs }\end{array}$ & $\begin{array}{l}\text { Displays } \\
\text { information on } \\
\text { how to use, } \\
\text { chapter } 8 \text {, and } \\
\text { chapter } 9\end{array}$ & It works \\
\hline 4 & $\begin{array}{l}\text { The user } \\
\text { selects the } \\
\text { about menu }\end{array}$ & $\begin{array}{l}\text { GvrEditorEmulato } \\
\text { r.cs } \\
\text { GvrPointerInputM } \\
\text { odule.cs } \\
\text { GvrControllerInpu } \\
\text { t.cs } \\
\text { GvrPointerPhysics } \\
\text { Raycaster.cs } \\
\text { GvrReticlePointer } \\
\text {.cs } \\
\text { Main Menu2.cs } \\
\text { menuload.cs } \\
\text { menu.cs } \\
\text { PlayerWalk.cs }\end{array}$ & $\begin{array}{l}\text { Displays } \\
\text { information } \\
\text { about the } \\
\text { developer and } \\
\text { about } \\
\text { laboratory }\end{array}$ & It works \\
\hline 5 & $\begin{array}{l}\text { The user } \\
\text { selects }\end{array}$ & $\begin{array}{l}\text { GvrEditorEmulato } \\
\text { r.cs }\end{array}$ & $\begin{array}{l}\text { Displays the ani } \\
\text { mated scene cha }\end{array}$ & It works \\
\hline
\end{tabular}

\begin{tabular}{|c|c|c|c|c|}
\hline & $\begin{array}{l}\text { the Joobsheet } \\
8 \text { menu }\end{array}$ & $\begin{array}{l}\text { GvrPointerInputM } \\
\text { odule.cs } \\
\text { GvrControllerInpu } \\
\text { t.cs } \\
\text { GvrPointerPhysics } \\
\text { Raycaster.cs } \\
\text { GvrReticlePointer } \\
\text {.cs } \\
\text { menuload.cs } \\
\text { menu.cs } \\
\text { PlayerWalk.cs }\end{array}$ & pter 8 & \\
\hline 6 & $\begin{array}{l}\text { The user } \\
\text { selects } \\
\text { the Joobsheet } \\
\text { menu } 9\end{array}$ & $\begin{array}{l}\text { GvrEditorEmulato } \\
\text { r.cs } \\
\text { GvrPointerInputM } \\
\text { odule.cs } \\
\text { GvrControllerInpu } \\
\text { t.cs } \\
\text { GvrPointerPhysics } \\
\text { Raycaster.cs } \\
\text { GvrReticlePointer } \\
\text {.cs } \\
\text { menuload.cs } \\
\text { menu.cs } \\
\text { PlayerWalk.cs }\end{array}$ & $\begin{array}{l}\text { Shows the anim } \\
\text { ated scene chapt } \\
\text { er } 9\end{array}$ & It works \\
\hline 7 & $\begin{array}{l}\text { The user } \\
\text { selects } \\
\text { the quiz menu }\end{array}$ & $\begin{array}{l}\text { GvrEditorEmulato } \\
\text { r.cs } \\
\text { GvrPointerInputM } \\
\text { odule.cs } \\
\text { GvrControllerInpu } \\
\text { t.cs } \\
\text { GvrPointerPhysics } \\
\text { Raycaster.cs } \\
\text { GvrReticlePointer } \\
\text {.cs } \\
\text { menuload.cs } \\
\text { menu.cs } \\
\text { PlayerWalk.cs } \\
\text { Cekskor.cs } \\
\text { Answer.cs }\end{array}$ & $\begin{array}{l}\text { Displays the qui } \\
\mathrm{z} \text { scene, } \\
\text { displays } \\
\text { questions and } \\
\text { choices and } \\
\text { displays scores }\end{array}$ & It works \\
\hline 8 & $\begin{array}{l}\text { Hovering ove } \\
\mathrm{r} \\
\text { the play anim } \\
\text { button }\end{array}$ & $\begin{array}{l}\text { GvrEditorEmulato } \\
\text { r.cs } \\
\text { GvrPointerInputM } \\
\text { odule.cs } \\
\text { GvrControllerInpu } \\
\text { t.cs } \\
\text { GvrPointerPhysics } \\
\text { Raycaster.cs } \\
\text { GvrReticlePointer } \\
\text {.cs } \\
\text { menuload.cs } \\
\text { menu.cs } \\
\text { PlayerWalk.cs } \\
\end{array}$ & $\begin{array}{l}\text { Running the } \\
\text { series animation } \\
\text { feature, and the } \\
\text { work step sound } \\
\text { feature }\end{array}$ & It works \\
\hline 9 & $\begin{array}{l}\text { Hovering } \\
\text { over the play } \\
\text { sound button }\end{array}$ & $\begin{array}{l}\text { GvrEditorEmulato } \\
\text { r.cs } \\
\text { GvrPointerInputM } \\
\text { odule.cs } \\
\text { GvrControllerInpu } \\
\text { t.cs } \\
\text { GvrPointerPhysics } \\
\text { Raycaster.cs } \\
\text { GvrReticlePointer } \\
\text {.cs } \\
\text { menuload.cs } \\
\text { menu.cs } \\
\text { PlayerWalk.cs }\end{array}$ & $\begin{array}{l}\text { Running voice } \\
\text { landing feature }\end{array}$ & It works \\
\hline
\end{tabular}


Based on the test table above, it can be seen that the functions of all menus in the laboratory virtual application are running well because each menu selected by the user is connected to each other and directs to the next display correctly.

\section{Testing Results by Questionnaires}

In this test, it is carried out among students to try the application and then the user provides a response by filling out the questionnaire that has been provided. The test was conducted by 50 respondents from the electrical engineering department of the telecommunications engineering study program and multimedia and network engineering. Following are the test results.

a. Applications Can Be Used Well

Figure 7 is a percentage by testing of questionnaires to 50 respondents of aspects of Application It Can Be Used In Good with ratings Good $78.4 \%$.

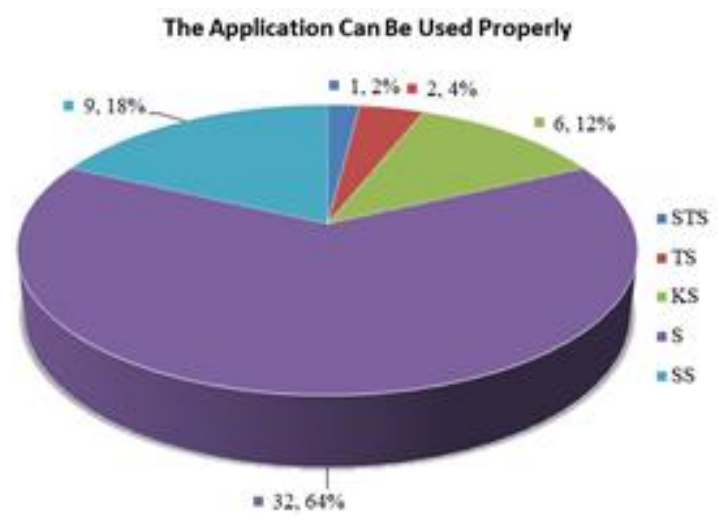

Figure 7 . Percentage of Questionnaire A application spec can be used properly

b. Features in the application are running as it should

Here in i Figure 8 is a percentage by testing of questionnaires to 50 respondents to the aspect Feature Set Now On Applications As should by votes Good 79.6 $\%$

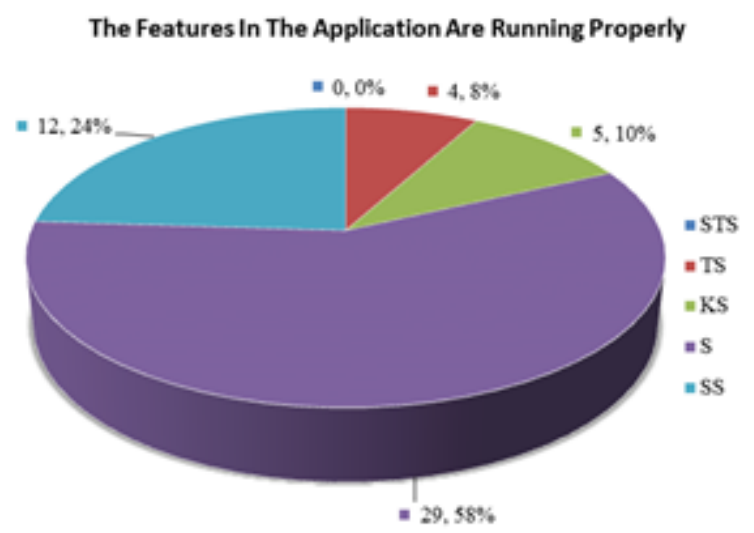

Figure 8. Percentage Questionnaire A spec feature In Application As It Runs Properly

c. With the Application You Can Feel Being In The Laboratory Room Of Basic Measurement And Instrumentation

Figure 9 is a percentage by testing of questionnaires to 50 respondents of aspects of the application Can Feel It Was In The Room Laboratory Instrumentation Measurement Fundamentals And with ratings Very Good $80.4 \%$.

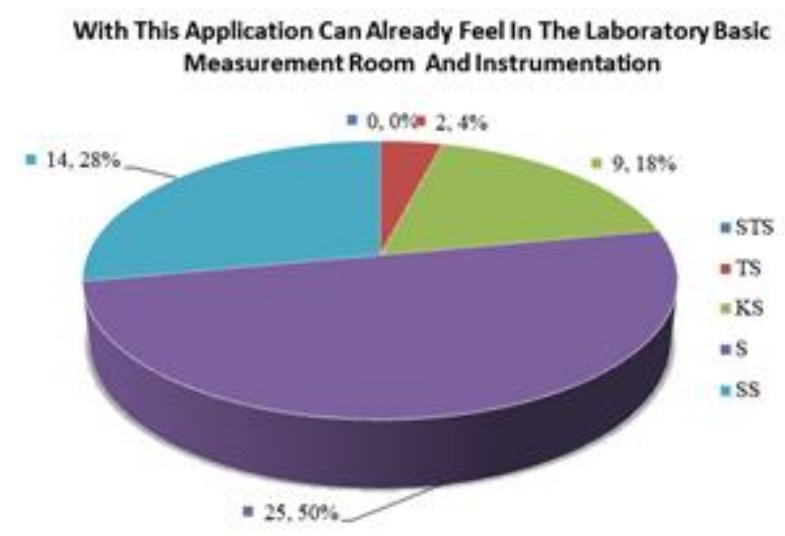

Figure 9 . Percentage of Aspect Questionnaire With Application Can Feel Being in the Laboratory Room for Basic Measurement and Instrumentation

d. Applications Can Help To Recognize And Study A Range Of Basic Measurement Laboratory Tools.

Figure 10 is the percentage of by testing of questionnaires to 50 respondents of aspects of Application D May Help To Know an tools- Networks 
Learning Tool Measurement Laboratory Basic rated Very Good $84 \%$.

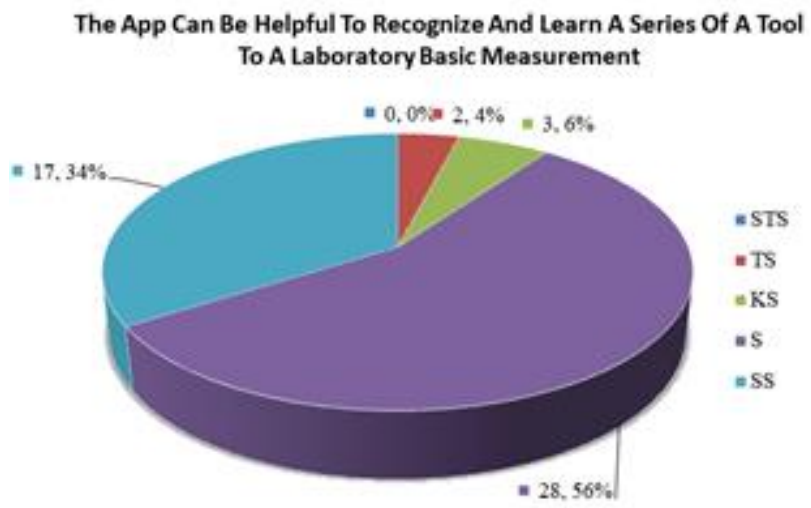

Figure 10 . The Percentage of the Application Aspect Questionnaire Can Help To Recognize And Study The Series Of Basic Measurement Laboratory Tools

e. Applications Can Be Useful For Students In The Future

Figure 11 is the percentage of by testing of questionnaires to 50 respondents of aspects of Application Can Work For Students Going forward with the assessment Very Good $88 \%$.

The Application Can Be Useful For Students in The Future

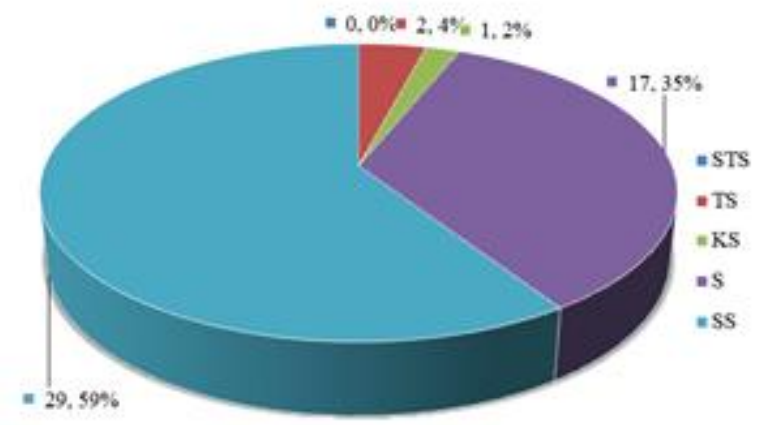

Figure 11. Percentage of Application Aspect Questionnaires Can Be Useful for Students in the Future

\section{Conclusion}

Based on the results of research carried out starting from the process of making and developing applications, the following conclusions are obtained:
1. The virtual laboratory application is made using Unity 3D, as a game engine, which allows users to see the laboratory background that is adjusted to the concept of the Electrical Engineering Instrumentation and Measurement Laboratory, Campus 2, Ujung Pandang State Polytechnic and see 10 types of practicum tools.

2. Based on the results of testing carried out using a questionnaire, it can be concluded that the use of the virtual laboratory application via smartphone devices is interpreted positively or declared very successful and can make it easier to access virtual laboratories .

In further application research, it would be better if the application development is carried out in the form of adding a joobsheet and oculus touch controller so that users can do practicum virtually in a virtual laboratory.

\section{Acknowledgement}

Author would like to thank Multimedia and Network Engineering Study Program, State Polytechnic of Ujung Pandang (SPUP) as well as the instrumentation and measurement laboratory of electrical engineering at SPUP campus 2 who have supported this research.

\section{References}

[1] A. Rifana, U. Neli, "Pengembangan Virtual Class untuk Pembelajaran Augmented Reality Berbasis Android", (Virtual Class Development for Android Based Augmented Reality Learning), JPTK UNY Vol. 21, No 2. pp. 114-122. 2012.

[2] B. Ahmad, "Pengembangan Media Pembelajaran Augmented Reality pada Mata Pelajaran Dasar Elektronika di SMK Hamong Putera 2 Pakem", (Development of Augmented Reality Learning Media in Basic Electronics Subjects at Hamong Putera 2 Pakem Vocational High School), Fakultas Teknik. Universitas Negeri Yogyakarta. 2017.

[3] B.H. Pratama, S. Agus, dan I. Edi, "Simulasi Pengenalan dan Instalasi PC berbasis Augmented Reality dengan Metode Single marker", (Augmented Reality-based PC Introduction and Installation Simulation with Single marker Method), Pendidikan Informatika FKIP Universitas Muhammadiyah Riau. Journal of Education Informatic Technology and Science (JeITS), Vol 1, Nomor 2, pp. 20-28. Agustus 2019.

[4] F. Melky, "Rancang Bangun Aplikasi Virtual Reality Laboratorium Fakultas Teknik Universitas Tanjungpura”, (Design and Build a Virtual Reality Application Laboratory, Faculty of Engineering, Tanjungpura University), Justin-Jurnal Sistem dan Teknologi Informasi, Vol. 3, No. 1. 2015. 


\section{INTEK Jurnal Penelitian}

[5] H. Jaya, "Laboratorium Virtual Mata Kuliah Praktikum Elektronika Digital", (Virtual Laboratory of Digital Electronics Practicum Course), Jurusan Pendidikan Teknik Elektronika Fakultas Teknik Universitas Negeri Makassar. Makassar. JETC, Vol. 4, No. 2, June 2010.

[6] H. Jaya, "Laboratorium Virtual Mata Kuliah Praktikum Elektronika Digital", (Virtual Laboratory of Digital Electronics Practicum Course), Jurusan Pendidikan Teknik Elektronika Fakultas Teknik Universitas Negeri Makassar. Makassar. JETC, Vol. 4, No. 2, June 2010.

[7] H. Jaya, "Pengembangan Laboratorium Virtual Untuk Kegiatan Praktikum dan Memfasilitasi Pendidikan Karakter di SMK", (Development of a Virtual Laboratory for Practicum Activities and Facilitating Character Education in Vocational High Schools) Makassar. Jurnal Pendidikan Vokasi, Vol. 2, No. 1, February 2012.

[8] I.S. Muhammad, Syahrir, dan M. Naufal, "Rancang Bangun Virtual Zoo Ecotourism Menggunakan Virtual Reality Sebagai Media Rekreasi Dan Edukasi Digital", (Design and Build a Virtual Zoo Ecotourism Using Virtual Reality as a Media for Recreation and Digital Education), Politeknik Negeri Ujung Pandang. Makassar. Prosiding Seminar Nasional Penelitian \& Pengabdian Kepada Masyarakat 2019, pp.69-74. 2019.

[9] N.B, Yudi, "Virtual Reality Technology Application for Conservation Architecture Building", Fakultas Teknik Sipil dan Perencanaan, Universitas Gunadarma. 2014.

[10] Anonym, "Pedoman Penulisan Proposal dan Skripsi Program Diploma Empat (D-4) Bidang Rekayasa dan Tata Niaga", (Guidelines for Writing Proposals and Thesis for Diploma Four (D-4) Programs in Engineering and Commerce), Makassar. Politeknik Negeri Ujung Pandang. 2016.

[11] P.N. Ardhana, "Penerapan Teknologi Virtual Reality Pada Perangkat Bergerak Berbasis Android Untuk Mendukung Terapi Fobia Laba-Laba (Arachnophobia)", (Application of Virtual Reality Technology on Android-Based Mobile Devices to Support Spider Phobia Therapy (Arachnophobia)), Jurnal Teknik ITS, Vol. 4, No. 1. Institut Teknologi Sepuluh Nopember (ITS). 2015.

[12] R.A. Erika, "Rancang Bangun Virtual Reality Psikologi Positif", (Positive Psychology Virtual Reality Design), Jurnal Elekterika, Vol. 16, No. 2. 2019.

[13] R.I. Agustina,I. dan Fauziah, "Implementasi Virtual Reality Pada Tur Virtual Monumen Nasional Menggunakan Unity 3d Algoritma Greedy Berbasis Android", (Implementation of Virtual Reality on Virtual Tour of National Monuments Using Unity 3d Greedy Algorithm Based on Android), JOINTECS, Journal of Information Technology and Computer Science, Vol. 3, No. 2. Universitas Nasional. Jakarta Selatan. 2018.

[14] Syahrir, N.Kurniati, K.Reski, "Implementasi Augmented Reality pada Museum La Galigo", (Augmented Reality Implementation at the La Galigo Museum), INTEK: Infomasi Teknologi, Vol. 5 No. 2, pp. 80-87. 2016. 
INTEK Jurnal Penelitian

Vol. 8, No. 1, pp. 59-66, April 2021 